\title{
THE INFESTATION DEGREE OF TREES WITH COMMON MISTLETOE VISCUM ALBUM L. AND THEIR HEALTH STATUS (ON THE EXAMPLE OF PRASZKA CITY)
}

\author{
Elżbieta Gołąbek' ${ }^{1}$ Jarosław Sławiński \\ 1 Department of Land Protection, University of Opole, Oleska 22, 45-052 Opole, Poland, e-mail: \\ golabek@uni.opole.pl; jarek19@uni.opole.pl
}

Received: 2017.09.03

Accepted: 2017.10.01

Published: 2017.11.01

\begin{abstract}
The research was carried out in September and October 2013. Their main aim was to obtain the information on the abundance and distribution of the common mistletoe in Praszka, assess the health status of the trees infested with this semi-parasite, and to determine its impact on the health of the hosts. All the trees with mistletoe were examined (in terms of the species, the number of semiparasite shrubs, the host health). The distribution and density hosts were presented on a prepared network with an area of 1 ha and Pearson's correlation factor was used to determine the relationship between the infestation degree of a host and its state of health. Only the typical subspecies of mistletoe - Viscum album L. subsp. album, which occupied 11 species of trees were found in the city of Praszka. These were mainly: black poplar Populus nigra L., smallleaved lime Tilia cordata L. and black locust Robinia pseudoacacia L. (they are also the most common or the frequent hosts in the country). The distribution of mistletoe in the city is uneven, and this is mainly due to the degree of urbanization, sunshine, noise, occurrence of the most common hosts as well as the presence of birds. It turned out that the largest groups of hosts were located along the roads in low building areas, on the peripheries of the city as well as in parks and cemeteries. The health condition of trees inhabited by mistletoe was generally good. There was a correlation between the number of mistletoe shrubs on the host and its health status (the greater the number of shrubs, the worse the health status of the host).
\end{abstract}

Keywords: Viscum album L., common mistletoe, degree of trees settlement, health condition of trees, Praszka

\section{INTRODUCTION}

Although mistletoe is one of well-known plants, it still arouses a lot of emotions in the world of science. First of all, it is caused by its quite vast expansion in the urbanised areas as well as its biological viability and resistance to various factors influencing the contemporary biocoenosis.

Mistletoe is a perennial evergreen shrub that belongs to the mistletoe family Viscaceae, order Santales [Kossak 1997]. As a semiparasite plant, it grows on branches of diverse deciduous and coniferous trees in the shape of round green clusters. It is found in Europe and Asia in the moderate climate zone [Koniuszy 1999, Witek 2007]. The research that was carried out in Hungary showed that in the beginning of the $20^{\text {th }}$ century, Viscum album L. occupied less than $10 \%$ of the country and since then its population has increased threefold [Varga et al. 2014].

The common mistletoe Viscum album L. is the most frequently encountered in our country [Fuławka 2004]. In Poland among this species, there are three other subspecies: common typical mistletoe Viscum album L. subsp. album, common fir mistletoe Viscum album L. subsp. abietis and common scattered mistletoe Viscum album L. subsp. austriacum [Ball 1993, Zuber 
2004, Ciaciura i in. 2008]. The latter two subspecies are less widespread. Most likely, this is due to the hosts' greater sensitivity to pollution [Grinn-Gofroń 1997].

The common mistletoe most often attacks the middle and the top zone of the crown. It appears much more rarely on the trunk of the tree [Ciaciura et al. 2008]. The distribution of mistletoe on the Italian poplar Populus nigra 'Italica' is specific. The poplar has a thin crown and almost vertically arranged branches (the semiparasite is found only in the internal zone) [Baratyński and Piórkowska 2003].

In Poland, mistletoe grows in the area of the whole country, but not everywhere in equal amount [Koniuszy 1999]. Its distribution depends on the occurrence of the most frequent hosts and on the routes of birds' flights such as thrush and waxwing [Bojarczuk 1971, Boratyński and Piórkowska 2003]. Mistletoe usually occurs in parks, cemeteries, on perimeter of forests and on trees along the roads in low building areas. It can also be found on trees next to water bodies and in the open spaces [Jurzyk and Kluczyński 2000, Boratyński and Piórkowska 2003].

Mistletoe is currently becoming a plant ecologically adjusted to grow in cities as it appears more and more often next to housing estates. The fact that it can spread in the urbanised areas quickly and adjust easily indicates its great biological viability and resistance [Grinn-Gofroń 1997].

The process of mistletoe germination depends on numerous factors including temperature and the access to light. The optimal temperature for germination is approx. $15-20^{\circ} \mathrm{C}$. In more severe conditions $\left(4-5^{\circ} \mathrm{C}\right)$ the germination process takes much more time and can last even 10-31 days, whereas in higher temperatures (approx. $18-32^{\circ} \mathrm{C}$ ) seeds start to sprout just after $2-8$ days. As far as light is concerned, mistletoe needs mainly blue rays which initiate the process of germination [Stypiński 1997]. It has to be pointed out that mistletoe needs light not only to germinate but also for its overall development; therefore, it is most frequently found in open spaces and well sunlit areas the [Stypiński 1978].

The research [Bojarczuk 1968] showed that Viscum album appears significantly more often on trees growing on soil rich in calcium as well as on soft wood species. A considerable number of species of its hosts tells us that mistletoe has excellent adaptation properties.

The widest spectrum of hosts is indicated by the common typical mistletoe. It can be found on linden trees, birch trees, poplars as well as on fruit trees such as apple trees and pear trees [Witek 2007]. According to the majority of authors, the black poplar Populus nigra is infested by mistletoe the most frequently. It does indeed belong to common hosts of Viscum album but only on certain areas of Poland. The density of the semi parasite is substantially different on particular types of trees and in different regions of the country [Stypiński 1997]. The domestic oak trees are quite rare hosts of mistletoe, as opposed to species from North America [Bojarczuk 1970]. It is also assumed that mistletoe attacks older trees at the age of 30-75 considerably more often [Kluczyński i Kończyk 2000].

In Hungary, no significant changes in hosts' specific composition have been observed for the last 90 years. It still appears on poplars Populus spp. and on white locust Robinia Pseudoacacia L. [Varga et al. 2014].

Mistletoe seeds are scattered by the plant itself involving such abiotic factors as wind or snow as well as with the help of animals [Sokołowski 1963]. The process of mistletoe seeds scattering takes place substantially more often with the participation of animals [Rukat 2008]. The main sowers among animals are birds. They scatter mistletoe in three basic ways: through knocking fruits over during feeding, as a result of husking the seeds and through excretion of undigested seeds [Grinn-Gofron 1997]. It is stated that there are 13 species of birds scattering mistletoe seeds. The most common are waxwings and birds from thrush family e.g. missel thrushes, blackbirds, songbirds. These birds choose calm places which is where the semi-parasite is found the most frequently [Bojarczuk 1968, Jurzyk i Kluczyński 2000].

The main goal of the research was to gain information about the abundance and distribution of mistletoe in the territory of Praszka, assessment of the health status of trees infested by this semi parasite and to determination of its influence on the health of the hosts.

\section{CHARACTERISTICS OF THE RESEARCH AREA}

Praszka is located in north-east part of Opole voivodeship, in Olesno district, in the commune of Praszka. The town is a supply and service base as well as cultural and educational centre for the 
farm region where it is situated. It takes up 9.45 $\mathrm{km}^{2}$ (approx. 9 thousand inhabitants). There are five parts belonging to the town territory: Kolonia pod Kowalami, Kolonia pod Rosochami, Kolonia pod Rozterkiem, Pilawy and Zawisna.

The described area belongs to moderately moist warm and moderately sunny region. The weather changes considerably throughout the year and diurnally. It is related to the fact that the commune is located at the border of lowlands and highlands of the Southern Poland. West and southwest winds prevail, usually weak, at the speed up to 3 metres per second. Strong winds occur quite rarely which constitutes only $0.2 \%$. The average annual air temperature around Praszka is $7.8^{\circ} \mathrm{C}$. The highest temperatures are recorded in July, with the average of $17.6^{\circ} \mathrm{C}$, and the lowest are recorded in January, with the average of $-2.7^{\circ} \mathrm{C}$. The average annual insolation around Praszka amounts to 1500 hours. The summer time, from May to August, is the most sunny, at that time the number of solar hours exceeds 6 per day. In December and January the insolation is the lowest. Generally, in the territory of Praszka commune, there are more cloudy days than sunny ones. All of the above mentioned parameters influence the length of the vegetative period, which starts after the $1^{\text {st }}$ of April and ends before the $1^{\text {st }}$ of November, lasting 210-220 days [Krzemiński 1999].

\section{RESEARCH METHODICS}

The research was carried out in September and October 2013. At that time, mistletoe is easy to localise and, simultaneously, it is still possible to assess the health status of the hosts. All of the in- fested trees were photographed, the species were marked and the mistletoe shrubs were counted.

On the basis of trunk and crown damages, the health condition of the trees was assessed. According to twelve-level scale devised by J. Duda (tab. 1), the health status is good if the total amount of the tree-stem and the tree-crown does not exceed 3. The health condition is bad if it falls between 4-7, and it is very bad if it exceeds 7 .

In order to assess the relationship between the infestation level of the host by the mistletoe and host health status, Pearson correlation coefficient was calculated, according to the formula

$$
\mathrm{r}=\frac{n \cdot \sum x_{i} y_{i}-\sum x_{i} \cdot \sum y_{i}}{\sqrt{\left[n \cdot \sum x_{i}^{2}-\left(\sum x_{i}\right)^{2}\right]\left[n \cdot \sum y_{i}^{2}-\left(\sum y_{i}\right)^{2}\right]}}
$$

where: $r$-Pearson correlation coefficient

$n$ - number of the trees

$X$ - number of mistletoe shrubs

$Y$ - host's health status

\section{RESULTS AND DISCUSSION}

The examined area included only the typical subspecies of the common mistletoe - Viscum album L. subsp. album. The number of localized infected trees equalled 241. The amount of the mistletoe shrubs that were found totalled to 3611 . Viscum album was found on 11 species of trees belonging to 10 types and 8 families. Searching for two other domestic mistletoe subspecies, i.e. the common scattered mistletoe and common fir mistletoe, brought no positive result; regardless of the fact that the common pine Pinus sylvestris L. appears in the territory of the city quite fre-

Table. 1. The health of trees (according to J. Duda) [Wika and Włoch 1994]

\begin{tabular}{|c|c|c|c|}
\hline \multirow{2}{*}{$\begin{array}{l}\text { Degree } \\
\text { of } \\
\text { damage }\end{array}$} & \multirow{2}{*}{$\begin{array}{l}\text { Damage size } \\
\text { tree-stem (S) }\end{array}$} & \multicolumn{2}{|c|}{ Note } \\
\hline & & tree-crown $(\mathrm{K})$ & \\
\hline 0 & $\begin{array}{l}\text { Not damaged cambium and } \\
\text { phellogen }\end{array}$ & No damage & $\begin{array}{l}\text { Growth of a new wood grain and } \\
\text { phloem in a whole girth of tree }\end{array}$ \\
\hline 1 & $\begin{array}{l}\text { Single injury or several injuries } \\
\text { together up to } 10 \mathrm{~cm} \text { of girth }\end{array}$ & $\begin{array}{l}\text { Up to } 15 \% \text { of tree crown, withered } \\
1-2 \text { branches or boughs girth at } \\
\text { base exceeding } 5 \mathrm{~cm}\end{array}$ & $\begin{array}{l}\text { Frost cracks, mechanical injuries, } \\
\text { unscarred cork in a trunk up to } 10 \mathrm{~cm}\end{array}$ \\
\hline 2 & Injuries of $10-25 \%$ of trunk girth & $\begin{array}{l}15-25 \%, \text { more than } 2 \text { injured } \\
\text { boughs }\end{array}$ & $\begin{array}{l}\text { At least } 3 / 4 \text { of trunk girth functions as a } \\
\text { conductor in wood and phloem }\end{array}$ \\
\hline 3 & Injuries of $25-50 \%$ of trunk girth & $25-50 \%$ & $\begin{array}{l}\text { Cambium functions preserved in at } \\
\text { least } 1 / 2 \text { of trunk girth }\end{array}$ \\
\hline 4 & Injuries of $50-75 \%$ of trunk girth & $50-75 \%$ & $\begin{array}{l}\text { At least } 1 / 4 \text { of trunk girth function as a } \\
\text { conductor }\end{array}$ \\
\hline 5 & Injuries more than $75 \%$ of trunk girth & More than $75 \%$ & $\begin{array}{l}\text { Less than } 1 / 4 \text { of trunk girth functions as } \\
\text { a conductor }\end{array}$ \\
\hline
\end{tabular}


quently. The percentage of the common mistletoe hosts is presented in the picture:

The received results indicate that the most common mistletoe host is the black poplar Populus nigra L. (38.8\%), small-leaved linden Tilia cordata L. (30.3\%), locust Robinia pseudoacacia L. (17.4\%) and balsam poplar Populus balsamifera L. (7.5\%). The rest of the species were infested in a considerably lower degree. It turned out that Viscum album L. subsp. album, grows first of all on species which are its most frequent or at least frequent hosts. These include Populus nigra, Tilia cordata and Robinia pseudoacacia which account for $80.5 \%$ of the total of hosts trees in Poland [Boratyński and Piórkowska 2003]. These trees do not need high quality soil and are less sensitive to drought and pollution, hence they frequently occur in the cities. In addition to that they are planted along roads, avenues and in the countryside.

It is proven that rowan Sorbus aucuparia L., common ash Fraxinus excelsior L. and domestic apple tree Malus domestica Borkh. are rare hosts in the examined area [Stypiński 1997]. During mistletoe's maturation process, birds visit apple trees frequently, therefore they are infested by the semi-parasite at that time (animals eat frozen apples then) [Bojarczuk 1968]. The very rare hosts in the city areas include warty birch Betula pendula L. and red oak Quercus rubra L.

Despite the high number of trees, mistletoe was not noticed on several species on which it does grow quite often but in different parts of Poland. These include: common hornbeam Carpinus betulus L., and sugar maple Acer saccharinum L. [Stypiński 1978, Jurzyk i Kluczyński 2000].
Common maple Acer platanoides L. also belongs to frequent hosts of the common mistletoe [Boratyński i Piórkowska 2003]. However, in the territory of Praszka, that fact was not confirmed.

Definitely, the highest number of Viscum album subsp. album was recorded on Populus nigra and Tilia cordata (2269 and 824 shrubs, respectively).

The degree of host infestation totalled from 1 to 121 shrubs of mistletoe on every tree - maximum 10 clusters $(59.8 \%)$ occurred more frequently; there were $1.6 \%$ of trees with number of shrubs over 80 . Percentage of hosts with defined number of Viscum album L. subsp. album is presented as follows: from 1 to 10 : $59.8 \%, 11-20: 17.4 \%$, 21-30: 7.1\%, 31-40: 5.0\%, 41-50: 3.3\%, 61-70: 1.7\%, 71-80: 0.8\%, 81-90: 0.4\%, 91-100: 0.4\%, 101-110: 0, 111-120: 0.4\%, over 120: 0.4\%.

The most numerous groups of mistletoe were observed on old linden trees and poplar trees. That fact can be confirmed by such authors as: Boratyńska and Boratyński [1976], Stypiński [1997] as well as Jurzyk and Kluczyński [2000]. Viscum album L. subsp. album appeared in the examined area the most often on mature and old trees, but the old ones were preferred.

The distribution of Viscum album subsp. album in the city area is quite uneven and dependent on the occurrence of its common hosts. Picture 2 presents the distribution and density of hosts in the examined area. For that purpose, the analysed area was divided into sectors of 2 ha within which the trees infested by mistletoe were counted.

It turned out that, the most numerous groups of mistletoe hosts are found along roads in low building areas, in the suburbs of the city as well as
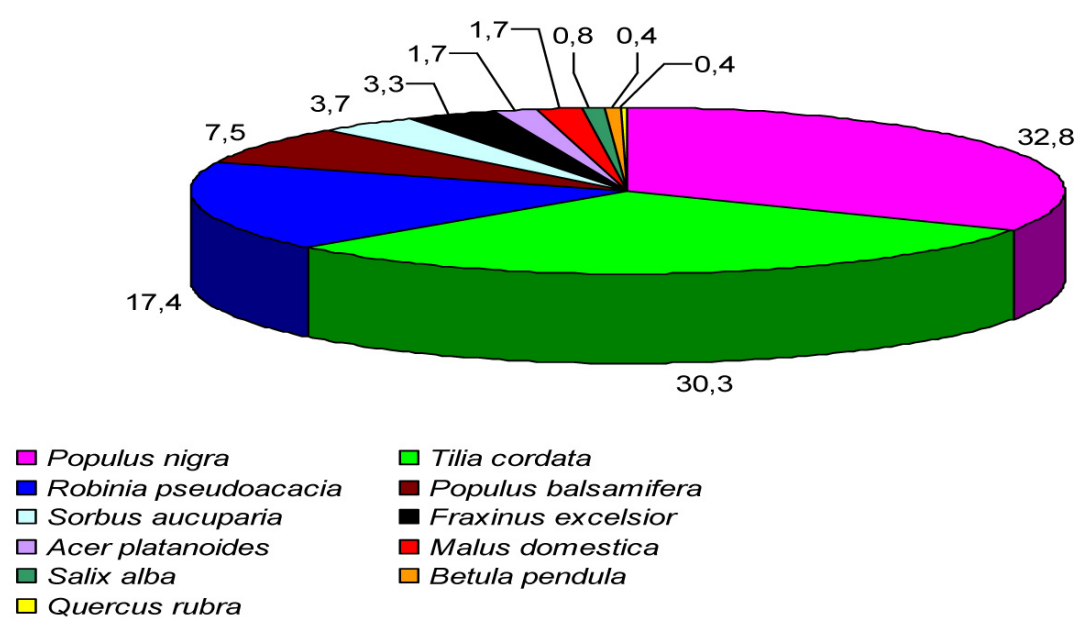

Figure 1. Percentage of common mistletoe Viscum album subsp. album hosts in Praszka 


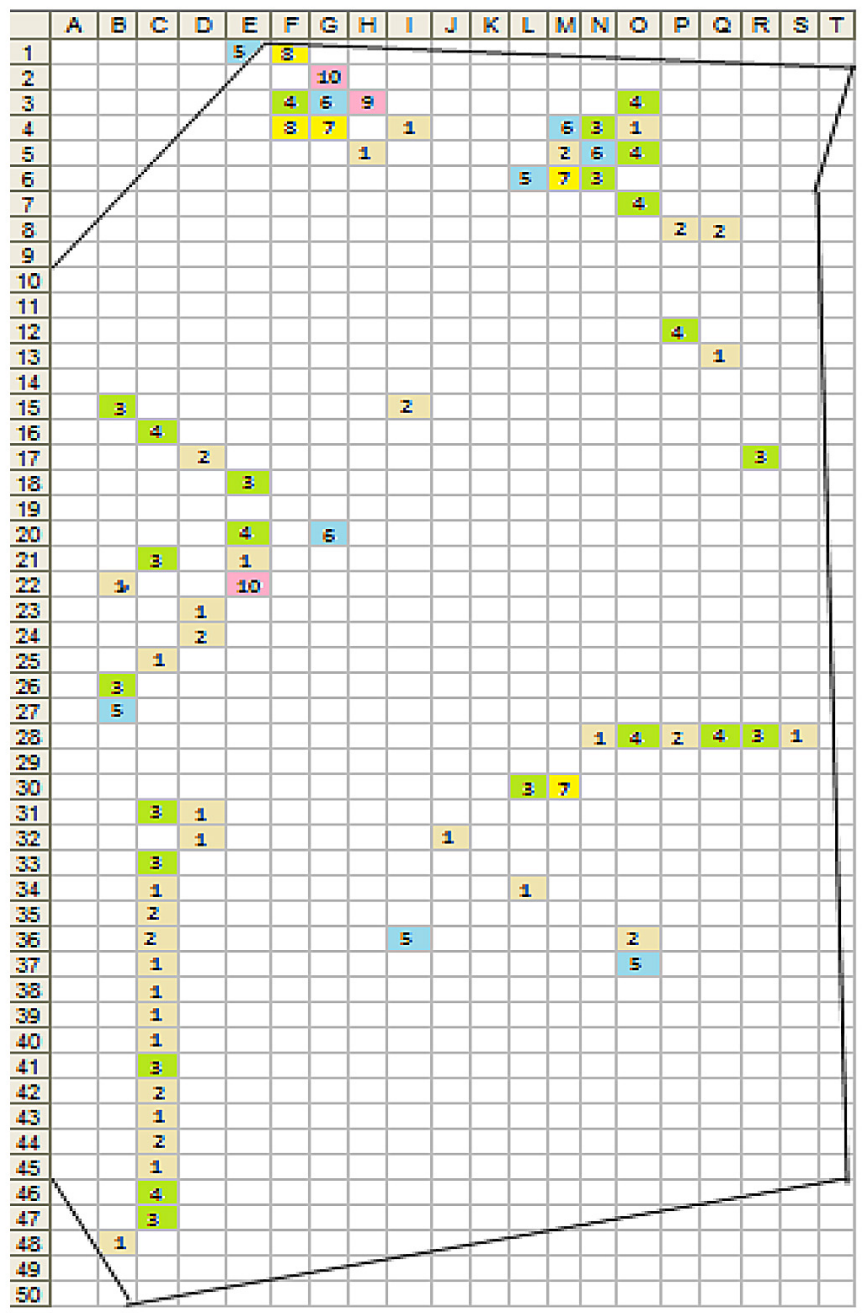

no density, very low density (1-2 hosts) low density (3-4 hosts) average density (5-6 hosts) high density (7-8 hosts) very high density ( $>9$ hosts)

Figure 2. Distribution and density of the common mistletoe Viscum album subsp. album (in sectors of 1 ha) in Praszka

in parks and cemeteries. On the other hand, single trees were recorded in the city centre and in the territory of new housing estates.

Low degree of tree infestation in the city centre can be caused by the annual trimming of crowns only to improve their aesthetics. In this area there are also a lot of young trees, which have not been infested yet.

The meaning of noise is also substantial, since it scares away the birds that bring the seeds of the semi-parasite [Boratyński i Piórkowska 2003].

The majority of the discovered Viscum album L. subsp. album was localized in the well sunlit places (the semi-parasite needs a lot of light in the beginning as well as in the later period of development) [Stypiński 1978].

Generally, high density of mistletoe hosts was observed in places where its biological conditions could be fulfilled.
Among all of the examined trees the largest group, i.e. $51.5 \%$ was constituted by pieces in a very fine health condition (the total for the trunk and the crown is 0 ). Minimum damages mainly of the crown (the total of 1 ) were observed in $15.8 \%$ of trees. There were $14.1 \%$ and $8.3 \%$ of hosts with the total of 2 and 3 , respectively. There were much fewer trees in a bad health condition. There were $6.2 \%$ and $2.5 \%$ of these trees with the total of 4 and 5 , respectively. There were only $2.5 \%$ of trees with the health status of 6 . The least, i.e. $0.4 \%$ of trees were in the health condition of 7 . That assessment was obtained by one tree only, i.e. the black poplar. The relationship between the number of semi-parasite and the host health status was determined (the value of the Pearson correlation coefficient totaled 0.7013 - the higher number of mistletoe clusters on a tree the worse its health condition). 


\section{CONCLUSIONS}

In the territory of Praszka the occurrence of only typical mistletoe subspecies - Viscum album L. subsp. album was stated. The semi-parasite infested 11 species of trees. There were 241 possessed hosts by the total of 3611 mistletoe shrubs. A considerable majority of trees infested by the semi-parasite belong to the following species: Populus nigra, Tilia cordata and Robinia pseudoacacia (they are also the most common or relatively common hosts in the territory of our country). The degree of infestation by the mistletoe shrubs totalled from 1 to 121 on every tree. The pieces attacked by maximum 10 individuals $(59.8 \%)$ were found the most often. The mistletoe appeared first of all on old trees (mainly linden trees and poplars).

Distribution of mistletoe in the territory of Praszka is uneven which is caused mainly by the degree of urbanization, sunshine, noise, occurrence of the most common hosts as well as the presence of birds. It turned out that the largest groups of mistletoe hosts were found along roads in low building areas, in the suburbs of the city as well as in parks and cemeteries. On the other hand, single trees were recorded in the city centre and in the territory of new housing estates.

The health status of the trees infested by mistletoe was generally good. There was a correlation between the number of mistletoe shrubs on the host and its health status (the greater the number of shrubs, the worse the health condition of the host).

\section{Acknowledgements}

Special thanks to Mrs. Monika Sałata for help in the realization of the project.

\section{REFERENCES}

1. Ball P. W. 1993. Viscum L. In: Tutin T. G., Burges N. A., Charter A. O., Edmondson J.R., Heywood V.H., Moore D.M., Valentine D.H., Walters S.M. \& Webb D. A. (eds.): Flora Europaea, vol. 1, Psilotaceae to Platanaceae. Cambridge University Press, Cambridge.

2. Bojarczuk T. 1968. Jemioła pospolita (Viscum album L.) w Arboretum Kórnickim. Aboretum Kórnickie 13, 123-132.

3. Bojarczuk T. 1970. O jemiole na dębach w Polsce. Rocznik Dendrologiczny 26, 84-85.
4. Bojarczuk T. 1971. Żywiciele jemioły pospolitej (Viscum album L.) w Polsce. Rocznik Dendrologiczny 25, 189-199.

5. Boratyńska K., Boratyński A. 1976. Viscum album L. Jemioła pospolita. W: Browicz K. (red.). Atlas rozmieszczenia drzew i krzewów w Polsce 19. PWN, Warszawa-Poznań, 9-19.

6. Boratyński A., Piórkowska M. 2003. Charakterystyka populacji jemioły pospolitej (Viscum album L. subsp. album) w Grudziądzu. Rocznik Dendrologiczny 51, 113-130.

7. Ciaciura M., Trypuć M., Więcław H. 2008. Jemioła pospolita typowa Viscum album subsp. album na terenie miasta i gminy Stargard Szczeciński. Zeszyty Naukowe Uniwersytetu Szczecińskiego. Acta Biologia 15, 69-76.

8. Fuławka J. 2004. Agresywna jemioła. Las Polski 13-14: 28

9. Grinn-Gofroń A. 1997. Jemioła niezwykła zwykła. Parki Narodowe 3, 30-31.

10. Varga I., Poczai P., Tiborcz V., Aranyi N.R., Baltazár T., Bartha D., Pejchal M., Hyvönen J. 2014. Changes in the Distribution of European Mistletoe (Viscum album) in Hungary During the Last Hundred Years. Folia Geobot. 49, 559-577.

11. Jurzyk S., Kluczyński B. 2000. Występowanie oraz charakterystyka ekologiczna jemioły pospolitej typowej (Viscum album L. subsp. album) w Słupsku. Rocznik Dendrologiczny 48, 77-91.

12. Koniuszy E. 1999. Jemioła pospolita (Viscum album L.). Aura 3, 3-4.

13. Kossak S. 1997. Jemioła. Echa leśne 1, 26-27.

14. Krzemiński T. 1999. Nad górną Prosną. Monografia Praszki. Wydawnictwo Uniwersytetu Łódzkiego. Łódź.

15. Rukat W. 2008. Inwazja jemioły na drzewach przyulicznych. Przegląd Komunalny 4(199), 62-65.

16. Sokołowski A. 1963. Kilka spostrzeżeń na temat występowania jemioły rozpierzchłej (Viscum laxum Boiss.) w południowo-wschodniej części Niziny Mazowiecko-Podlaskiej. Rocznik Dendrologiczny 17, 159-163.

17. Stypiński T. 1978. Występowanie jemioły pospolitej (Viscum album L. subsp. album P. W. Ball 1964) na Pojezierzu Mazurskim. WSP Olsztyn.

18. Stypiński P.T. 1997. Biologia i ekologia jemioły pospolitej (Viscum album, Viscaceae) w Polsce. Fragmenta Floristica Et Geobotanica. Series Polonica. Supplementum 1. Instytut Botaniki im. W. Szafera, PAN Kraków.

19. Wika S., Włoch W. (red.) 1994. Aleja Husarii Polskiej z alejami bocznymi na tle rezerwatu Łężczak w Kotlinie Raciborskiej. Dyrekcja Parku Krajobrazowego „Cysterskie Kompozycje Krajobrazowe Rud Wielkich", Rudy Wielkie.

20. Witek R. 2007. Jemioła - szanowany pasożyt. Przyroda Polska 12, 18-19.

21. Zuber D. 2004. Biological flora of Central Europe: Viscum album L. Flora 199, 181-203. 